\title{
Preparing Future Human Resources in Language Learning: EFL Student Teachers' Voices' Academic Stressors
}

\author{
Marzul Hidayat \\ Universitas Jambi, Jambi, Indonesia \\ Dery Mulya Putri \\ Universitas Jambi, Jambi, Indonesia \\ Fortunasari Fortunasari \\ Universitas Jambi, Jambi, Indonesia \\ Fridiyanto Fridiyanto \\ UIN Sulthan Thaha Saifuddin Jambi \\ Akhmad Habibi \\ Universitas Jambi, Jambi, Indonesia \\ Amirul Mukminin \\ Universitas Jambi, Jambi, Indonesia
}

\begin{abstract}
Preparing good and skillful human resources in language learning is avoidable, particularly for the country like Indonesia which is still a developing one. The intent of this qualitative study in the case study tradition was used to explore what the academic factors that made EFL student teachers as future human resources feel stressed in English language learning at one public university in Jambi, Sumatra, Indonesia. We adopted a qualitative case study approach. Using a convenience case strategy, we interviewed EFL student teachers. The primary data for our study were collected through the face-to-face interviews. The interviews were conducted in English, audio-taped, and directly transcribed verbatim. The interviews data were analyzed through reading line by line all the transcriptions to find major themes. We found eight salient and interweaved themes led EFL student teachers as future human resources feel stressed in English language learning including (1) internal and external factors of choosing English as a major,(2) pleasure and displeasure feeling in studying English in university, (3) positive and negative responses to the lecturers in studying English, (4) positive and negative influences of friends in English major, (5) feeling about academic activities (credits, assignments, subjects and examinations) (6) feeling about discussion or presentations, (7) the most pressure or stress issue during the learning processes, and (8) dealing with the stressors. The findings of this study shed light on our understanding of the academic factors that made EFL student teachers as future human resources feel stressed in English language learning.
\end{abstract}

Index Terms — future human resources in learning English, stress, student teachers

\section{INTRODUCTION}

Preparing good and skillful human resources in the lights of developing a country is a major effort of every country in the world including being able to communicate in a global language like English. Having skillful human resources in communicating with other people from different countries and culture is a must in today's situation (Abrar et al., 2018; Erlina et al., 2019; Marzulina et al., 2019). To achieve such as a goal, a country through its educational sector should prepare and produce their individuals to be able to use English both inside and outside the country. In Indonesia, many young people still believe that taking English major at a university has a good prospect in future. However, the motivation of becoming EFL student teachers could emerge from themselves or others. After becoming EFL student teachers, many of them may enjoy the academic process of the program while there are some students who may feel trapped in the program that may make them feel stressed to fulfill academic demands. According to Hoy and Woolfok (1993), learning as a challenging process is a main stressor for the learners since they are needed to familiarize their knowledge. Moreover, Harwood (2010) says that among the school or college subjects, languages are impelled by stress, as language is a multi-skill subject; interpersonal communication, cognitive, and physical skills. Furthermore, Chen (1999) state that language barriers may generate harm and tangible threat to students whose first language is not English 
while Alqahtani and Alajmi (2013) say that language as a simply human activity and as an overwhelming means of interpersonal communication is a source of stress.

Stress may attack any people in any situation. One of them is stress in language learning. Stress in language learning is part of academic stress. It may happen when people or students learn a new language like English. Learning English as a foreign language is easy for some people, but it may not be easy for some other people as English is not their first language. Learners of English as a foreign language frequently express their feeling of stress or anxiety when they learn to communicate in English Language. Previous literature has indicated that stress is part of academic process. The findings of Mukminin's study $(2012 ; 2013)$ indicated that language issues such as difficulties in listening, speaking, reading and writing in English as several sources of stress for language learners. Additionally, Hashemi (2011) found that language anxiety originated from several factors such as learners' own sense of self, language learning difficulties, differences in learners' target language cultures, and differences in social status of the speakers and interlocutors. Additionally, in terms of speaking, Mukminin et al. (2015) found five major sources of stress including (1) low speaking skill due to lack of vocabulary and grammar, (2) fear of negative responses from others, (3) low self-esteem to speak in English, (4) fear of being evaluated by teachers, and (5) cultural influences to speak English due to a more teacher-centred style while Öztürk and Gürbüz (2014) found that pronunciation, immediate questions, fears of making mistakes and negative evaluation were the main sources of EFL speaking anxiety.

Even though some studies (e.g., Alqahtani \& Alajmi, 2013; Mukminin, 2012; Chen, 1999) have been documented related to the students' stress in the context of language learning, research on stress of EFL student teachers as future human resources in English language learning in Indonesian context is still understudied. This fact encouraged us to do research on stress of EFL student teachers as future human resources in English language learning in one of the public universities in Indonesia. To achieve the purpose of the research, two questions guided our study: (1) What do the academic factors make EFL student teachers as future human resources feel stressed in English language learning? (2) How do they deal with the stressors?

\section{METHODOLOGY}

In order to expand our knowledge of the academic factors make EFL student teachers as future human resources feel stressed in English language learning, we adopted a qualitative case study approach. Therefore, the purpose of this study was to report the qualitative findings on the academic factors that make EFL student teachers as future human resources feel stressed in English language learning at one public university in Jambi, Sumatra, Indonesia. As this study focused on EFL student teachers as future human resources in one English education program, a qualitative case study was appropriately adopted (Mukminin, 2012; Mukminin, 2015; Mukminin, 2017). Merriam (1998) wrote that a qualitative case study was an intensive and holistic description, explanation, and analysis of "a bounded system" (p. 27) or phenomenon such as a person, a program, an institution, a process, a social unit, a group, and a policy.

\section{A. Research Site, Access, Sampling Procedures, and Participants}

The researchers conducted the current research in one English education program at one public university in Jambi province, Sumatra Island, Indonesia. To get access to research site, we obtained permission from the English language program chair and the dean of faculty of teacher training and education. In this study, a purposeful sampling with a convenience case strategy was used to discover, understand, and gain more insight on the academic factors that make EFL student teachers as future human resources feel stressed in English language learning. In conducting this research, the researchers planned to have more participants through the convenience case strategy. However, we finally had 6 students consisting of 3 males and 3 females voluntarily agreed to participate in the research.

TABLE 1

PARTICIPANTS' BACKGROUND INFORMATION

\begin{tabular}{|l|l|l|l|l|}
\hline Participant & Gender & GPA & Major & Current Status \\
\hline 1 & Male & Less than 3.00 & English education program & BA/the last year \\
\hline 2 & Female & Less than 3.00 & English education program & BA/the last year \\
\hline 3 & Female & Less than 3.00 & English education program & BA/the last year \\
\hline 4 & Female & Less than 3.00 & English education program & BA/the last year \\
\hline 5 & Male & Less than 3.00 & English education program & BA/the last year \\
\hline 6 & Male & Less than 3.00 & English education program & BA/the last year \\
\hline
\end{tabular}

\section{B. Data Collection, Analysis, and Trustworthiness}

The primary data for our study were collected through the face-to-face interviews. The interviews did not take place once. It depended on the participants' time and willingness. During the interview, we began asking participants to talk about their experiences related the students' stress in learning English as a foreign language. We, then, asked them more specific questions related to our research inquiry. Each student teacher was given an option to answer to interview questions in either Indonesian or in English. All student teachers elected to use English. As a result, any grammatical errors might appear in the excerpts. The interviews were conducted in English, audio-taped, and directly transcribed verbatim. The second interview was also conducted because we needed more data from each student teacher. The 
second interview lasted approximately one hour for each participant at a location of the participant's choice. Additionally, to support the interview data, we also used a demographic background survey to obtain participants' backgrounds including age, gender, semester, and others.

For the analysis of the data, the demographic data analyzed descriptively. The researchers used demographic profile survey in order to get the information about the participants before doing the interview. The interview data that had been recorded were transcribed. The transcription of the interviews was done by the researchers. After transcribing the interviews, the researchers divided them into some categories or themes. The next step was to divide the data to be related to categories by doing a process of marking segments of data (text data) with symbols, descriptive words, or categories.

To confirm the credibility of the inquiry or the "trustworthiness" (Lincoln \&Guba 1985, p. 300) of our study, the researchers had done following procedures. Firstly, the researchers had an interview to the personal students about their stress in learning English, and that interview was recorded as evidence. Also, the researchers check with the colleagues that served as member checking.

\section{FINDINGS AND DISCUSSION}

The purpose of the research was to explore the qualitative findings on the academic factors that make EFL student teachers as future human resources feel stressed in English language learning at one public university in Jambi, Sumatra, Indonesia. Based on the interview data analyses, eight salient themes that emerged in this research were (1) internal and external factors of choosing English as a major,(2) pleasure and displeasure feeling in studying English in university, (3) positive and negative responses to the lecturers in studying English, (4) positive and negative influences of friends in English major, (5) feeling about academic activities (credits, assignments, subjects and examinations) (6) feeling about discussion or presentations, (7) the most pressure or stress issue during the learning processes, and (8) dealing with the stressors

\section{A. Internal, External Factors, and Combination of the Two Factors}

In this study, the reasons why the participants chose English as their major could be classified into three categories, they were internal, external, and combination of the two factors. Out of six participants, two of them reported that external factors motivated them to choose English as their major. It indicated that they chose English major was not their willingness, but it was their parents who encouraged them to opt it. For example,

Participant 1: This is not mine, because this is my mother want me to choose English major in this university.

Participant 2: It is because my parents ask me to enter this major.

On the other hand, there were three participants who had internal reasons of opting English as their major. Particularly, one participant stated that she loved English. Even though, her field of study trained to be an English teacher, but she did not intend to be a teacher. Similarly, other two participants were interested in English on accounts of international language. They reflected,

Participant 4: Actually I chose English education because I like it, but I actually I don't want to be English teacher, yes just like English.

Participant 5: I think I like English speaking English is the most of the speaking of the world.

Participant 6: My consideration maybe English is an [a] universal language and I like it.

Only one participant declared who had both internal and external motivation in pursuing English education. In other words, her major was opted not only because of her parents' choice but also due to her own option. For example,

Participant 3: Because maybe my parents want me, I am here, and the second I like too, I like English too.

The data from the interviews indicated that both internal and external factors were the reasons of choosing the English major for their field of study. From the findings of this study, three participants were influenced by internal factors while two participants had external reasons in making a decision; it was because of their parents' choices. The last, there was one participant who conveyed that her choice was supported by her parents as well as her own willingness.

\section{B. The Feeling of Pleasure and Displeasure in Studying English}

One of the crucial themes was to know how the participants felt about studying English in the faculty of teacher training and education. Among all participants, two of them reflected that they had no doubt that studying English was enjoyable. Their positive responses could be seen as follows,

Participant 5: I think I feel happy and enjoy.

Participant 6: I think studying English in this university.. Great.. I enjoy.

However, the remaining participants stated different things from those two participants above. They reported that sometimes they were not comfortable studying English. Out of four participants who were displeased studying in English department, three of them declared that it was influenced by lecturers. Moreover, there was one participant who reflected that sometimes she was anxious and shy, but she did not give any specific reasons. The statements of them could be seen as follows,

Participant 1: I feel good but sometimes our lecturers treat us like stupid persons. 
Participant 2: Sometimes I'm bored it depends on the lecturers.

Participant 3: Sometimes I'm bored but I still enjoy it, but it depends on the lecturers too.

Participant 4: I feel happy but sometimes I feel nervous and sometimes like shame.

The statements above indicated that the majority of the participants responded negatively to what they were feeling about studying English. Boring classes were the reasons of it. Even, one of the participants reported that there was a lecturer who underestimated him in the class. Certainly, it psychologically affected students' enthusiasm in learning. However, it depended on who taught them. Nevertheless, there were two participants who reported that they were happy in taking English major.

\section{Positive and Negative Responses to the Lecturers in Studying English}

The quality of the lecturers belongs to the most important factor in the provision of high quality education. Surely, the qualified lecturers will determine a quality of education. In this study, participants gave their views what they were thinking about the lecturers in their major. The interviews showed that there were three participants who criticized their lecturers when they taught them in the English major. For example,

Participant 1: students can't understand what the lecturers talk about.

Participant 2: Killer, boring, old styles...our lecturers.

Participant 3:Some are killers, some are boring old school

Yet, the positive responses also came from participants. Two of them admitted that there were good lecturers who could make students enjoy the class during the learning processes. Even though there was one student who declared that she did not totally understand what the lecturers were saying, but she was happy with the lecturers. For example,

Participant 4: I feel happy but actually I feel confused about what he or she says because when they're talking in English, I do not understand.

Even though the finding above indicated that some lecturers were good. On the other hand, it was also stated that some of them should be evaluated both academic and non-academic competences. Academically, as reported by the participants, the lecturers were supposed to upgrade their teaching styles. Moreover, with regard to non-academic sides, the lecturers were demanded to behave well with the students. Because some of the participants declared that there were not good lecturers when teaching them.

\section{Positive and Negative Influences of Friends in English Major}

Participants came from a variety of backgrounds. Nevertheless, regarding friendship, our participants only had one view; they felt that all their friends were awesome. All participants admitted that their friends brought positive atmospheres in their academic life in studying English. Even, they supported each others with generosity. They were really impressed with their mates as stated the followings,

Participant 1: I got good friends and support me.

Participant 2: My friends are kind and good.

The data from the interviews indicated that there were no negative influences of friends in English major to all the participants. In addition, the study showed that their friends very encouraged them.

\section{E. Feeling about Academic Activities (Credits, Assignments, Subjects, and Examination)}

Feeling stressed about credit hours, completing a bachelor degree in Indonesia takes 4-5 years. In some countries, it only needs 3 years. Compared with the number of credits is also more in Indonesia. In this study, the participants shared their mind that they felt stressed about the credits. There were five participants who had a problem regarding the number of credits offered. It could be shown in the following statements,

Participant 2: Oh yes, of course, I feel stressed with the credit hours.

Participant 3: Feel stressed? Yes of course I feel stressed.

Participant 6: I got stressed when I have to complete about twenty four credit hours.

Conversely, out of six participants, there was one participant reported that he did not feel stressed with credit hours in English major. Participant 1: "I did not really feel stressed about credit hours." The data indicated that most of students felt stressed toward a number of credits offered. It would be more stressful once they took full credit in a particular semester (twenty four credit hours). Moreover, in Indonesia, the students were not given a freedom to choose their courses in the area of specialization on what they need and what they are interested in. Also, they try to take as many credit hours as possible to reach the target of the study.

Feeling stressed about assignments, students are demanded to learn more autonomously. The assignment is one of the ways to create an independent learning for them. Yet too many papers assigned in the same time as the other works made students feel stressed. In this study participants reported, for example,

Participant 2: I always feel stressed. I have too much homework in one semester.

Participant 4: Yes, it really burdens me a lot and finally I feel stressed.

The data indicated that all of the participants were grumbling about assignment. So, it made them stressed. Even, some participants thought that the assignment given to students was too much. In reality, students were not only demanded on academic competence, but also non-academic one like taking part in the college organizations, volunteering, training, and so forth. 
Feeling stressed about the courses, even though English major focuses on English language teaching. Yet, some others courses are also part of curriculum in the English major such as literature and linguistics. There were some subjects that would make students stressed. They were poetry, cross culture understanding, research, and subjects relating to linguistic including morphology and phonology.

Participant 2: Yes, Poetry. It makes me stressed because I don't like a poem.

Participant 3: Yes, in Linguistics because the lecturer is very boring and makes that me feel that the subject is bored too.

Participant 4: for CCU, the assignment is very hard and I feel stressed.

On the contrary, there was one student who declared that none of subjects made him stressed. In the other word, the subjects offered in the English major are good for him. Out of six participants, there were 5 participants who would feel stressed of certain subjects with different reasons. Particularly, the difficult subjects were the one related to literature and linguistics. It meant that they did not have any difficulties with the courses which focused on English language teaching, like curriculum and material development, teaching English as a foreign language, educational profession, language testing, and so forth.

Feeling stressed about examinations, the students pursuing their studies are not only to get better knowledge, but also to get better score in order to be easy to have a proper job in the future. Sometimes, they tend to be grade-oriented students. This orientation could make them stressed. According to Struthers, Perry, and Menec (2000), students' academic stress is inversely related to their course grades. Ideally, the students are supposed to minimize stress in order to get a good score in examination.

Participant 2: Nervous and confused for the exams

Participant 3: Examination, I feel really stressed about how I must do it in that time.

A different view was stated by one participant. He reported that he did not feel stressed in the examination. Participant 1 stated confidently that he felt good in doing it.

Participant 1: I feel good to do it.

The examples of excerpts above describe participants' feelings and thoughts in which majority of them were stressed in examination. Their stress was expressed in the form of being confused, nervous, and afraid. In other words, mentally, they were not ready to have examinations in English.

\section{F. Feeling about Discussion or Presentations}

In presentation, both English competence and public speaking ability are needed. Most of the participants stated their negative feeling in presentation. Implicitly, they shared their disagreement toward such as a kind of the learning method. Their unhappy expressions could be seen as follows,

Participant 1: I don't agree with presentation in here because students must know about their topic. I feel nervous when I am asked to do that.

Participant 2: I'm nervous, stressed, and sometimes I'm shaking when holding a paper.

The data interviews above indicated that among the participants of the study, participants felt stressed with a group discussion and presentations in learning English in their major.

\section{G. The Most Pressure or Stress Issue during the Learning Processes}

Regarding the most pressure or stressed issues during the learning processes, out of six participants, four of them admitted that they felt stressed when the lecturers asked them to use English. The participants declared that they were confused to respond to it. For example,

Participant 1: sometimes lecturers ask the questions immediately and it makes me blank.

Participant 2: sometimes I [am] nervous and stress [ed] when the lecturer [s] ask me to use English and I'm confused to answer.

In addition, there was one participant who admitted that the most pressure thing was because he had lack of vocabulary.

Participant 4: I have limited vocabulary and bad grammar to speak and I feel stressed.

The last participant reported that he did not understand what the lecturers were speaking. So, he feel really stressed in the class.

Participant 5: I think If I feel stress[ed] as I don't understand what lecturers speaks and I cannot understand about he says.

The statements above indicated that there were three main points that the participants felt the most stressed during the learning process. First, they felt stressed to be asked in English. Second, they had lack of vocabulary, and third they did not understand what the lecturers said.

\section{H. Deal with the Stressors}

The last theme explores the participants' ways in coping with their stress. Each participant had his or her own strategy to solve the stressors during the learning processes in the English major.

Participant 1: Talking [sharing] about my problems with other[s].

Participant 2: I play with my brothers, my phone, Google, and games. 


\section{Participant 3: I go to travelling with my friends and talk about that with them. \\ Participant 4: I talk with my best friend about my problems in English. \\ Participant 5: if I feel stressed I can go to canteen to eat and make a joke with my friends. \\ Participant 6: Playing a game and travelling}

The data from the interviews indicated that among participants there were various ways that would be done to solve their stress in learning English. Each participant had his or her own comfortable method in overcoming the problems. In short, they shared their problems with their friends or did something that could make them happy (eating, using mobile phone, joking, etc.), and travelled around with the mate(s). In terms of academic ways, they discussed with their friends who they think are smart. They discussed the stressors with their smart friends.

It was hard to decide what the academic factors that made EFL student teachers as future human resources feel stressed in English language learning at one public university in Jambi, Sumatra, Indonesia and what factors played in a greater part than others as all of the factors seemed to be involvedly interwoven. Among the factors of students' stress in learning English, the participants experienced both internal and external factors of choosing English as their major. It meant that the stress was not because of who opted their field of study but how they dealt with it.

Additionally, participants in this study reported that they felt unhappy in studying English. The participants stated that they were not satisfied with some teaching staffs who taught the courses. Many of them complained about the lecturers' competences. So, participants' unhappiness could make them lazy in studying English. According to Kottasz (2005), poor tutors or lecturers are the reasons for students' non-attendance at lectures and tutorials. Additionally, the lecturers play an important role in teaching-learning processes. How they engage with student teachers is an important thing in educational life. This study found that there were some lecturers who did not treat every student fairly which led participants to be bored during the learning processes. Agrawal and Thakur (2014) said that the school environment was the result of the interaction of teachers- students' relationship, teachers' academic and professional qualification, teachers' teaching. As found in this study, both academic and non-academic competences of the lecturers were needed to be improved as participants felt uncomfortable with academic atmospheres in the research site. In terms of feeling stressed about academic activities (credits, assignments, subjects, and examination), this study showed that majority of the participants had problems with their academic demands. This finding is consistent with the findings of Lin and Huang's (2014) study. In terms of feeling about presentations, the findings showed that the participants were not comfortable with the presentation method which was conducted during the courses, because it made them afraid, confused, and nervous. Similarly, it was also found by Gaibani and Elmenfi (2014), a significant number of respondents had indicated that they experienced speaking anxiety for a wide range of reasons which made them to be more fearful, confused, trembling, feel very tense, feel very rigid, make their heart beat fast, make them nervous, make them make mistakes and make them perform poorer when delivering speech, attending interviews or during classroom presentations. With regard to the most pressured or stressful issue during the learning process, each participant had various responses including they were feeling stressed to be asked in English by their lecturers, they had lack of vocabulary, and they did not understand what the lecturers said in English. The finding of the study is consistent with what Liu (2007) found in that lack of vocabulary, low English proficiency and memory disassociation were the sources leading to English language speaking anxiety.

\section{CONCLUSION}

Preparing good and skillful human resources in language learning is avoidable, particularly for the country like Indonesia which is still developing. The intent of our qualitative design in the case study tradition was used to explore what the academic factors that made EFL student teachers as future human resources feel stressed in English language learning at one public university in Jambi, Sumatra, Indonesia. We found eight salient and interweaved themes led EFL student teachers as future human resources feel stressed in English language learning including (1) internal and external factors of choosing English as a major,(2) pleasure and displeasure feeling in studying English in university, (3) positive and negative responses to the lecturers in studying English, (4) positive and negative influences of friends in English major, (5) feeling about academic activities (credits, assignments, subjects and examinations) (6) feeling about discussion or presentations, (7) the most pressure or stress issue during the learning processes, and (8) dealing with the stressors. Implications for future research and education policies and programs can be drawn from the findings of this study. To deal students' stress, educational policymakers and lecturers at departmental levels could encourage students to learn English through e.g., providing motivating teaching media (films and using audio-visual aids) or providing sufficient language learning facilities.

\section{REFERENCES}

[1] Abrar, Mukhlas, Mukminin, Amirul., Habibi, Akhmad., Asyrafi, Makmur, Makmur, \& Marzulina, Lenny. (2018). If our English isn't a language, what is it? Qualitative Report 23(1), 129-145.

[2] Agarwal \& Thakur. (2014). Influence of environments on the English learning of students in India. International Journal on Arts, Management and Humanities, 3(1), 5-8.

[3] Alqahtani, A. A., \& Alajmi, S. S. (2013). Psychological stress in language learning: A contemporary view beyond teaching methods. Journal of Education and Practice, 4(5), 168-171. 
[4] Chen, C.P. (1999). Professional issues: Common stressors among international college students: Research and counseling implications. Journal of College Counseling, 2(1), 49-65.

[5] Erlina, D., Marzulina, L., Astrid, A., Desvitasari, D., Sapriati, R. S., Amrina, R. D., Mukminin, A., \& Habibi, A. (2019). Linguistic intelligence of undergraduate EFL learners in higher education: A case study. Universal Journal of Educational Research, 7(10), 2143-2155.

[6] Gaibani, A., \& Elmenfi, F. (2014). The role of gender in influencing public speaking anxiety. International Journal of Gender and Women's Studies, (2), 105-116.

[7] Harwood, J. (2010). The contact space: A novel framework for intergroup contact research. Journal of Language and Social Psychology, 29(2), 147-177.

[8] Hashemi, M. (2011). Language stress and anxiety among the English language learners. Procedia - Social and Behavioral Sciences, 30, $1811-1816$.

[9] Hoy, W. K., \& Woolfolk, A. E. (1993). Teachers' sense of efficacy and the organizational health of schools. The Elementary School Journal, 93, 355-372.

[10] Kottasz, R. (2000). Reasons for student non-attendance at lectures and tutorials: an analysis. Investigations in university teaching and learning, 2(2), 5-16.

[11] Lincoln, Y. S., \& Guba, G.B. (1985). Naturalistic inquiry. Newbury Park, CA: Sage Publications.

[12] Lin, S.H., \& Huang, Y.C. (2014). Life stress and academic burnout. Active Learning in Higher Education, 15(1), 77-90.

[13] Liu, M. (2007). Anxiety in oral English classrooms: A case study in China. Indonesian Journal of English Language Teaching, 3(1), 119-137.

[14] Marzulina, L., Mukminin, A., Erlina, D., Astrid, A., Ajriyah, N., Holandiyah, M., \& Habibi, A. (2019). The grammatical awareness of student teachers: The case of an English education study program in Indonesia. Universal Journal of Educational Research, 7(9), 1847-1859.

[15] Merriam, S.B. (1998). Qualitative research and case study applications in education. San Francisco, CA: Jossey-Bass.

[16] Mukminin, A. (2012). Acculturative experiences among Indonesian graduate students in US higher education: Academic shock, adjustment, crisis, and resolution. University of Pittsburgh, USA-Excellence in Higher Education, 3(1), 14-36.

[17] Mukminin, A., \& McMahon, B. J. (2013). International graduate students' cross-cultural academic engagement: Stories of Indonesian doctoral students on an American campus. Qualitative Report, 18(35), 1-19.

[18] Mukminin, A., Ali, R. M., \& Ashari, M. J. F. (2015). Voices from within: Student teachers' experiences in English academic writing socialization at one Indonesian teacher training program. Qualitative Report, 20(9), 1394-1407.

[19] Mukminin, A., Kamil, D., Muazza, M., \& Haryanto, E. (2017). Why teacher education? Documenting undocumented female student teachers' motives in Indonesia: A case study. Qualitative Report, 22(1), 309-326.

[20] Öztürk, G., \& Gürbüz, N. (2014). Speaking anxiety among Turkish EFL learners: The case at a state university. Journal of Language and Linguistic Studies, 10(1), 1-17.

[21] Struthers, C.W., Perry, R.P., \& Menec, V. H. (2000). An examination of the relationship Among academic stress, coping, motivation, and performance in college. Research in Higher Education, 41(5), 581-592.

Marzul Hidayat is an assistant professor, Universitas Jambi, Faculty of Teacher Training and Education, Indonesia. His research interests include education, applied linguistics, language teaching, TESOL, TEFL, language education, international education, educational policy and language policy.

Dery Mulya Putri has a BA in English education and MS in educational management, Universitas Jambi, Indonesia. Her research interests include language teaching, TESOL, TEFL, language education, educational policy and language policy.

Fortunasari is an assistant professor, Universitas Jambi, Faculty of Teacher Training and Education, Indonesia. Her research interests include education, applied linguistics, language teaching, TESOL, TEFL, and language education.

Fridiyanto is an assistant professor, UIN Sulthan Thaha Saifuddin Jambi, Indonesia. His research interests include education, language education, multicultural education, educational policy and management.

Akhmad Habibi is an assistant professor, Universitas Jambi, Faculty of Teacher Training and Education, Indonesia.

Amirul Mukminin is a full professor, Universitas Jambi, Faculty of Teacher Training and Education, Indonesia. His research interests include education, language education, international education, educational policy and language policy. 